\title{
PENERAPAN MODEL PEMBELAJARAN PROBLEM BASED LEARNING (PBL) DIMODIFIKASI NUMBERED TERHADAP KEMAMPUAN PEMAHAMAN KONSEP MATEMATIS SISWA
}

\author{
${ }^{1}$ Dini Nuraeni \\ (Pendidikan Matematika, FKIP, Universitas Muhammadiyah Sukabumi) \\ dnanuraini3@gmail.com
}

\begin{abstract}
ABSTRAK
Penelitian ini bertujuan untuk mengetahui apakah terdapat perbedaan kemampuan pemahaman konsep matematis antara siswa yang menggunakan model pembelajaran Problem Based Learning (PBL) Dimodifikasi Numbered dengan siswa yang menggunakan model pembelajaran PBL dan siswa yang menggunakan model pembelajaran Langsung. Serta untuk mengetahui model pembelajaran manakah yang lebih baik dari ketiga model pembelajaran tersebut. Penelitian ini menggunakan metode penelitian eksperimen dengan desain eksperimen semu (quasi experimen) bentuk the nonequivalent posttest control group design. Populasi dalam penelitian ini adalah seluruh siswa kelas VIII SMP Negeri 2 Ciemas Kabupaten Sukabumi tahun ajaran 2017/2018. Teknik pengumpulan data yang digunakan dalam penelitian ini menggunakan teknik tes dan tek non tes. Teknik pengumpulan data melalui teknik tes menggunakan data postes. Sedangkan, pengumpulan data melalui teknik non tes ditempuh melalui dokumentasi, wawancara dan observasi. Instrumen penelitian yang digunakan dalam penelitian ini yaitu intrumen tes dan intrumen non tes, instrument non tes yang digunakan yaitu pedoman wawancara dan lembar observasi. Hasil penelitian menunjukan bahwa: 1) Terdapat perbedaan kemampuan pemahaman konsep matematis antara siswa yang menggunakan model pembelajaran PBL dimodifikasi numbered, siswa yang menggunakan model pembelajaran PBL, dan siswa yang menggunakan model pembelajaran langsung; 2) Kemampuan pemahaman konsep matematis siswa yang menggunakan model pembelajaran PBL dimodifikasi numbered lebih baik daripada siswa yang menggunakan model pembelajaran PBL; 3) Kemampuan pemahaman konsep matematis siswa yang menggunakan model pembelajaran PBL dimodifikasi numbered lebih baik daripada siswa yang menggunakan model pembelajaran langsung; 4) Kemampuan pemahaman konsep matematis siswa yang menggunakan model pembelajaran PBL tidak lebih baik daripada siswa yang menggunakan model pembelajaran langsung.
\end{abstract}

Kata Kunci : Problem Based Learning, Numbered, Kemampuan Pemahaman Konsep Matematis

\section{PENDAHULUAN}

Pendidikan pada hakekatnya merupakan syarat mutlak bagi pengembangan sumber daya manusia dalam menuju masa depan yang lebih baik. Melalui pendidikan dapat dibentuk manusia yang mampu membangun dirinya sendiri dan bangsanya, maka dari itu perlu dilakukan peningkatan mutu pendidikan (Utomo dkk, 2014: 6). Berdasarkan Undang-Undang No. 20 Tahun 2003 tentang Sistem Pendidikan Nasional menyatakan bahwa: "Pendidikan adalah usaha sadar dan terencana untuk mewujudkan suasana belajar dan proses pembelajaran agar peserta didik secara aktif mengembangkan potensi dirinya untuk memiliki kekuatan spiritual keagamaan, pengendalian diri, kepribadian, kecerdasan, akhlak mulia, serta keterampilan yang diperlukan bagi dirinya, masyarakat, bangsa dan negara".

Susanto (2014:185) menyatakan bahwa "matematika adalah suatu mata pelajaran yang perlu diajarkan pada semua jenjang pendidikan, mulai dari sekolah dasar sampai perguruan tinggi”. Sejalan dengan itu, Depdiknas menyatakan bahwa "mata pelajaran matematika perlu diberikan kepada semua siswa mulai dari sekolah dasar untuk membekali siswa dengan kemampuan berfikir logis, analitis, sistematis, kritis, dan kreatif serta kemampuann bekerjasama". Hal tersebut menunjukkan betapa pentingnya peranan matematika dalam dunia pendidikan dan perkembangan teknologi saat ini. Sebagaimana tercantum dalam Permendiknas No. 22 Tahun 2006 tentang standar isi yang mengemukakan bahwa "matematika merupakan ilmu universal yang mendasari perkembangan teknologi modern, mempunyai peran penting dalam berbagai ilmu disiplin, dan memajukan daya pikir manusia".

Salah satu tujuan matematika pada pendidikan adalah agar siswa memiliki kemampuan memahami konsep matematika, menjelaskan keterkaitan antar konsep dan mengaplikasikan konsep, secara luwes, akurat, efisien, dan tepat dalam pemecahan masalah dimana kita ketahui bersama peranan penting matematika dalam mendukung proses manusia menjalani kehidupan (Suleman, 2013: 2). Fokus pada hakikat pembelajaran matematika adalah pemahaman konsep, hal tersebut dikarenakan konsep-konsep dalam matematika tersusun secara sistematis, hirarkis, dan logis mulai dari sederhana sampai kompleks (Retnowati, 2013:15). Oleh karena itu, jika siswa menguasai konsep materi prasyarat, maka siswa tersebut akan lebih mudah dalam proses pemahaman konsep materi selanjutnya. Permasalahan 
yang saat ini dihadapi oleh guru mata pelajaran matematika di sekolah adalah penguasaan siswa terhadap beberapa materi pokok bahasan matematika, terutama untuk mengingat konsep dalam waktu terbatas yang telah diajarkan (Anggoro, 2015: 72).

Berdasarkan hasil wawancara dengan guru matematika kelas VIII SMP Negeri 2 Ciemas Kabupaten Sukabumi nilai UAS semester genap kelas VII SMP Negeri 2 Ciemas Kabupaten Sukabumi tahun ajaran 2016/2017 dari 188 siswa hanya 28 siswa yang melebihi nilai 72. Data nilai UAS selengkapnya dapat dilihat dilampiran 18. Permasalahan tersebut dapat disebabkan oleh banyak faktor, Kartini (2014: 94) berpendapat bahwa "salah satu penyebabnya adalah strategi pembelajaran yang dilaksanakan oleh guru yang masih bersifat tradisional, yaitu siswa masih diperlakukan sebagai objek belajar dan guru lebih dominan berperan dalam proses pembelajaran dengan memberikan konsepkonsep atau prosedur-prosedur baku, sehingga pada pembelajaran ini hanya terjadi komunikasi satu arah". Hal tersebut sejalan dengan pendapat Retnowati (2013:15) "pembelajaran matematika seharusnya berpusat pada siswa bukan pada guru".

Berdasarkan hal tersebut, pembelajaran yang dilakukan harus dirancang sedemikian rupa sehingga pemahaman konsep matematis siswa dapat tercapai dengan baik. Dengan kata lain, pembelajaran yang dilakukan tentunya harus tepat dengan melibatkan siswa secara aktif (student center) dan tidak hanya menerima pengetahuan yang diberikan oleh guru. Salah satu model pembelajaran yang memberi kondisi belajar aktif dan dapat mendukung siswa dalam pencapaian pemahaman siawa yaitu melalui Model Problem Based Learning (PBL). "PBL merupakan suatu model pembelajaran inovatif yang memberi kondisi belajar aktif kepada peserta didik dalam kondisi dunia nyata" (Yamin, 2013:62). "PBL lebih mengedepankan konsep pemahaman dari pada konsep hafalan, hal tersebut dapat dilihat dari penyelidikan dari suatu masalah yang diangkat menjadi materi dimana siswa berusaha memahami apa yang menjadi masalah dan kemudian menyelesaikan masalah tersebut" (Pratama, 2016: 6).

Pelaksanaan model PBL diawali dengan diberikannya permasalahan. Masalah ini digunakan untuk mengaitkan rasa keingintahuan serta kemampuan analisis siswa dan inisiatif atas materi pelajaran. Dengan permasalahan tersebut, siswa diarahkan untuk berdiskusi dan bekerjasama secara berkelompok untuk mencari solusi permasalahan yang diberikan, dimana siswa mempunyai kesempatan dalam memlilih dan melakukan penyelidikan apapun baik di dalam maupun di luar sekolah sejauh itu diperlukan untuk memecahkan masalah, selanjutnya mereka mempresentasikan hasil kerja mereka, serta menarik kesimpulan.

Selain memberi kondisi belajar yang aktif, siswa juga harus memiliki rasa tanggungjawab penuh dalam memahami materi baik secara berkelompok maupun individu. Salah satu alternatif untuk mengatasi masalah tersebut adalah dengan penerapkan model PBL yang dimodifikasi dengan memberikan penomoran (numbered) pada masing-masing anggota kelompok siswa. Penomoran ini bertujuan untuk menentukan perwakilan kelompok yang akan mempresentasikan hasil diskusi kelompoknya. Penentuan nomornya dipilih secara acak oleh guru. Hal ini mengakibatkan siswa dalam setiap kelompok menjadi lebih bertanggungjawab untuk memahami materi pembelajaran dan lembar kerja kelompok yang akan dipresentasikan.

Berdasarkan pemaparan di atas dapat disimpulkan bahwa dalam model pembelajaran PBL dimodifikasi numbered adalah suatu model pembelaajaran yang memberi kondisi belajar aktif serta menuntut siswa bertanggungjawab secara individu maupun kelompok. Hal tersebut sejalan dengan Ramlan (2013: 111) "dalam proses pembelajaran matematika, aktivitas belajar akan lebih efektif jika siswa berperan aktif. Siswa tidak hanya mendengarkan cermah dari guru maupun mencatat yang ditulis guru di papan tulis, tetapi siswa berusaha mencoba mengerjakan soal sendiri dengan bimbingan dari teman maupun guru. Siswa harus kreatif, ulet dan memiliki sikap percaya diri akan kemampuan yang dimilikinya". Oleh karena itu perlu diadakan suatu penelitian mengenai penerapan model pembelajaran Problem Based Learning (PBL) dimodifikasi Numbered terhadap kemampuan pemahaman konsep matematis siswa.

Rumusan masalah dalam penelitian ini sebagai berikut: 1) Apakah terdapat perbedaan antara kemampuan pemahaman konsep matematis siswa yang menggunakan model pembelajran PBL dimodifikasi numbered, kemampuan pemahaman konsep matematis siswa yang menggunakan model pembelajaran PBL, dan kemampuan pemahaman konsep matematis siswa yang menggunakan model pembelajaran langsung?. 2) Apakah kemampuan pemahaman konsep matematis siswa yang menggunakan model pembelajaran PBL dimodifikasi numbered lebih baik dibandingkan dengan kemampuan pemahaman konsep matematis siswa yang menggunakan model pembelajaran PBL?. 3) Apakah kemampuan pemahaman konsep matematis siswa yang menggunakan model pembelajaran PBL dimodifikasi numbered lebih baik dibandingkan dengan kemampuan pemahaman konsep matematis siswa yang menggunakan model pembelajaran langsung?. 4) Apakah kemampuan pemahaman konsep matematis siswa yang menggunakan model pembelajaran PBL lebih baik dibandingkan 
dengan kemampuan pemahaman matematis siswa yang menggunakan model pembelajaran langsung?.

Tujuan penelitian ini sebagai berikut : 1) Untuk mengetahui perbedaan kemampuan pemahaman konsep matematis siswa yang menggunakan model pembelajran PBL dimodifikasi numbered, kemampuan pemahaman konsep matematis siswa yang menggunakan model pembelajaran PBL, dan kemampuan pemahaman konsep matematis siswa yang menggunakan model pembelajran langsung. 2) Untuk mengetahui perbandingan kemampuan pemahaman konsep matematis antara siswa yang menggunakan model pembelajaran PBL dimodifikasi numbered dengan siswa yang menggunakan model pembelajaran PBL. 3) Untuk mengetahui perbandingan kemampuan pemahaman konsep matematis antara siswa yang menggunakan model pembelajaran PBL dimodifikasi numbered dengan siswa yang menggunakan model pembelajaran langsung. 4) Untuk mengetahui perbandingan kemampuan pemahaman konsep matematis antara siswa yang menggunakan model pembelajaran PBL dengan siswa yang menggunakan model pembelajatan langsung.

Manfaat dari penelitian penerapan model pembelajaran dimodifikasi numbered ini yaitu dapat meningkatan kemampuan pemahaman konsep matematis siswa dengan menjadikan siswa belajar lebih aktif dan bertanggungjawab dalam kegiatan kelompok dan dapat menambah wawasan ilmu pengetahuan, sebagai usulan positif bagi guru matematika.

\section{METODE PENELITIAN}

Metode penelitian yang digunakan dalam penelitian ini adalah metode penelitian eksperimen. Metode penelitan ini digunakan untuk mencari pengaruh perlakuan tertentu terhadap yang lain dalam kondisi yan terkendalikan. Desain penelitian yang digunakan dalam penelitian ini adalah quasi experimental bentuk the non equivalent posttes only control group design. Pada desain ini masing-masing sampel diberikan perlakuan yang sudah ditentukan. Kemudian setelah berakhirnya penelitian masing-masing sampel diberi posstest untuk mengetahui kemampuan akhirnya. Kemapuan akhir yang dimaksud dalam penelitian ini adalah kemampuan pemahaman konsep matematis siswa. Sampel dibagi menjadi tiga kelompok, yaitu dua kelas eksperimen dan satu kelas kontrol.

\section{Tabel 1}

\section{Desain penelitian}

$\begin{array}{ccc}\text { Kelas eksperimen I } & \mathbf{X}_{1} & \mathbf{O} \\ \text { Kelas eksperimen II } & \mathbf{X}_{2} & \mathbf{O} \\ \text { Kelas control } & \mathbf{X}_{3} & \mathbf{O}\end{array}$

Keterangan:

$\mathrm{X}_{1}=$ Perlakuan dengan model pembelajaran PBL dimodifikasi numbered

$\mathrm{X}_{2}=$ Perlakuan dengan model pembelajaran PBL

$\mathrm{X}_{3}=$ Perlakuan dengan model pembelajaran langsung

$\mathrm{O}=$ Posttest.

Populasi dalam penelitian ini yaitu seluruh siswa kelas VIII Sekolah Menengah Pertama Negeri 2 Ciemas Kabupaten Sukabumi tahun ajaran 2017/2018 yang berjumlah 188 siswa dan terbagi ke dalam lima kelas. Penentuan sampel dilakukan dengan sampel random atau acak. Teknik pengambilan sampel yang digunakan dalam penelitian ini adalah cluster random sampling/area random sampling, yaitu pengacakan sampel daerah. Cluster random sampling/acak kelas dapat dilakukan jika kelas dalam populasi yang akan diambil sebagai sampel memiliki karakteristik yang homogen/relative homogen/ tidak ada kelas unggulan (Lestari dan Yudhanegara, 2015: 105).

Pemilihan kelas dilakukan dengan cara mengundi kelima kelas pada populasi, dimana dari lima kelas diambil menjadi tiga kelas, yaitu dua kelas eksperimen dan satu kelas kontrol. Undian pertama yaitu kelas VIII E dengan 37 siswa menjadi kelas eksperimen I dengan perlakuan model pembelajaran PBL dimodifikasi numbered, undian kedua yaitu kelas VIII B dengan 38 siswa menjadi kelas eksperimen II dengan perlakuan model pembelajaran PBL, dan undian yang ketiga yaitu kelas VIII D dengan 38 siswa menjadi kelas kontrol dengan perlakuan model pembelajaran langsung.

Teknik pengumpulan data yang digunakan dalam penelitian ini yaitu, teknik tes dan teknik non tes. Teknis non tes yang digunakan ada 3 macam yaitu: 1) dokumentasi; 2) wawancara; dan 3) observasi. Istrumen penelitian yang digunakan dalam penelitian ini yaitu tes pemahaman konsep, pedoman wawancara, dan lembar observasi.

Langkah-langkah pada metode tes (Lestari dan Yudhanegara, 2015: 105) sebagai berikut:

a. Menentukan indikator dari variabel yang diteliti dalam penelitian;

b. Menyusun kisi-kisi instrumen;

c. Menentukan kriteria penskoran/penilaian;

d. Merumuskan item-item pertanyaan atau pernyataan;

e. Melakukan uji coba instrumen;

f. Memberikan penskoran/penilaian;

g. Melakukan analisis hasil uji coba instrumen;

h. Menentukan instrument yang akan digunakan dalam penelitian.

Sebelum instrument tes kemampuan pemahaman konsep matematis diberikan kepada kelas eksperimen I, kelas eksperimen II dan kelas kontrol. Instrumen tes terlebih dahulu diuji cobakan kepada kelas yang sebelumnya 
sudah mendapatkan materi operasi aljabar. Uji coba tes dilakukan pada siswa kelas IX A SMP Negeri 2 Ciemas Kabupaten Sukabumi dengan tujuan untuk mengetahui kualitas instrument tes tersebut. Soal tes dapat digunakan apabila sudah terbukti mempunyai kualitas yang baik, yaitu memenuhi kriteria validitas, tingkat kesukaran, daya pembeda dan reliabilitas.

Teknik analisis data yang digunakan dalam penelitian ini yaitu uji prasyarat dan pengujian hipootesis. Uji prasyarat yang digunakan diantaranya yaitu, uji normalitas, uji homogenitas dan uji keseimbangan. Sedangan uji hipotesis yang digunakan yaitu uji prasyarat analisis variansi (uji normalitas dan uji homogenitas), uji anava satu jalur sel tak sama kemudian dilanjutkan dengan uji lanjut pasca anava.

\section{HASIL DAN PEMBAHASAN}

\section{Deskripsi Hasil Kemampuan Awal Pemahaman Konsep Matematis}

Data tentang kemampuan awal pemahaman konsep matematis siswa diperoleh dari hasil UAS semester II kelas VII SMP Negeri 2 Ciemas Kabupaten Sukabumi Tahun Ajaran 2016/2017. Data awal ini digunakan untuk mengetahui kemampuan pemahaman konsep matematis siswa ketiga kelas yang diambil memiliki kemampuan yang sama. Uji statistik yang digunakan untuk menguji normalitas yaitu menggunakan metode Liliefors pada taraf signifikan $(\alpha)$ 0,05. Rangkuman hasil perhitungan uji normalitas kemampuan awal pemahaman konsep matematis sampel dapat dilihat pada Tabel 3 di bawah ini:

Tabel 3

\section{Rangkuman Hasil Uji Normalitas Kemampuan Awal}

\begin{tabular}{|c|c|c|c|c|c|c|}
\hline No. & Sampel & $\mathbf{N}$ & $\mathbf{L}_{\text {hitung }}$ & & Keputusan & $\begin{array}{c}\text { Ketera } \\
\text { ngan }\end{array}$ \\
\hline 1 & $\begin{array}{l}\text { Kelas } \\
\text { Eksperimen } \\
\text { I }\end{array}$ & 37 & 0,13 & 0,15 & $\begin{array}{c}\mathrm{H}_{0} \\
\text { diterima }\end{array}$ & $\begin{array}{c}\text { Norma } \\
\mathbf{l}\end{array}$ \\
\hline 2 & $\begin{array}{l}\text { Kelas } \\
\text { Eksperimen }\end{array}$ & 38 & 0,08 & 0,14 & $\begin{array}{c}\mathrm{H}_{0} \\
\text { diterima }\end{array}$ & $\begin{array}{c}\text { Norma } \\
\mathbf{l}\end{array}$ \\
\hline
\end{tabular}

Berdasarkan Tabel 3 diatas menunjukan bahwa kelas eksperimen I memperoleh $\mathrm{L}_{\text {hitung }}=0,13$ dengan $\mathrm{L}_{\text {tabel }}=0,15$, kelas eksperimen II memperoleh $\mathrm{L}_{\text {hitung }}=$ 0,08 dengan $\mathrm{L}_{\text {tabel }}=0,14$ dan kelas kontrol memperoleh $\mathrm{L}_{\text {hitung }}=0,11$ dengan $\mathrm{L}_{\text {tabel }}=0,14$. Karena dari ketiga sampel menunjukan $\mathrm{L}_{\text {hitung }}<\mathrm{L}_{\text {tabel }}$, maka $\mathrm{H}_{0}$ diterima. Sehingga dapat disimpulkan bahwa kelas eksperimen I, kelas eksperimen II dan kelas kontrol berasal dari populasi yang berdistribusi normal.

Setelah uji normalitas, selanjutnya yaitu uji homogenitas. Uji homogenitas variansi digunakan untuk mengetahui apakah variansi-variansi dari sejumlah populasi sama atau tidak. Populasi yang mempunyai variansi sama disebut populasi-populasi yang homogen. Pada penelitian ini uji statistik yang digunakan yaitu menggunakan metode bartlett pada taraf signifikan $(\alpha)$ 0,05. Rangkuman hasil perhitungan uji homogenitas kemampuan awal pemahaman konsep matematis sampel. dapat dilihat pada Tabel 4.3 di bawah ini:

\section{Tabel 4}

\section{Rangkuman Hasil Uji Homogenitas Kemampuan}

\begin{tabular}{rllll} 
Nama Variabel & $\mathbf{X}^{2}{ }_{\text {hitung }}$ & $\mathbf{X}_{\text {tabel }}$ & $\begin{array}{c}\text { Keputus } \\
\text { an }\end{array}$ & Ket. \\
\hline $\begin{array}{l}\text { Kelas Eksperimen I, } \\
\text { Kelas Eksperimen II }\end{array}$ & $\mathbf{0 , 8 5}$ & $\mathbf{5 , 9 9}$ & $\begin{array}{l}\mathbf{H}_{\mathbf{0}} \\
\text { diterima }\end{array}$ & $\begin{array}{l}\text { Hom } \\
\text { ogen }\end{array}$
\end{tabular}

dan Kelas Kontrol

Berdasarkan hasil perhitungan diperoleh $\chi^{2}$ hitung $=$ 0,85 dengan $\chi_{\text {tabel }}^{2}=5,99$. Karena $\chi^{2}$ hitung berada diluar daerah kritis, maka $\mathrm{H}_{0}$ diterima. Sehingga dapat disimpulkan bahwa sampel berasal dari populasi yang bervarians homogen.

Sebelum eksperimen dilakukan, terlebih dahulu harus dilakukan uji keseimbangan, hal ini dimaksud agar hasil dari eksperimen benar-benar akibat dari perlakuan yang berbeda, bukan karena pengaruh yang lain. Uji keseimbangan digunakan untuk menguji rataan kelas eksperimen dan kelas kontrol. Dengan uji prasyarat analisis bahwa sampel berasal dari populasi berdistribusi normal dan homogen. Data yang digunakan dalam uji keseimbangan ini adalah data UAS. Pada penelitian ini, uji statistik yang digunakan untuk menguji keseimbangan yaitu menggunakan uji anava satu jalur dengan sel tak sama pada taraf signifikan $(\alpha) 0,05$. Hasil perhitungan uji anava satu jalan dihasilkan $\mathrm{F}_{\text {hitung }}=0,08$ dengan $\mathrm{F}_{0,05 ; 2 ; 110}$ $=3,08$ dengan daerah kritis $\mathrm{DK}=\{\mathrm{F} F>3,08\}$. Ini

berarti $\mathrm{F}_{\text {hitung }}=0,08 \notin \mathrm{DK}$, sehingga $\mathrm{H}_{0}$ diterima. Dengan demikian dapat disimpulkan bahwa kemampuan awal antara kelas eksperimen I, kelas eksperimen II dan kelas kontrol mempunyai kemampuan awal yang sama/homogen.

\section{Deskripsi Hasil Kemampuan Akhir Pemahaman Konsep Matematis (Posttest)}

Data ini diperoleh dari hasil posttest kemampuan pemahaman konsep matematis yang diperoleh setelah dilakukan perlakuan, untuk kelompok siswa yang belajar dengan menggunakan model pembelajaran PBL dimodifikasi numbered, kelompok siswa yang belajar dengan menggunakan model pembelajaran PBL dan kelompok siswa yang menggunakan model pembelajaran langsung. Sebelum melakukan pengujian hipotesis kemampuan akhir pemahaman konsep matematis diperlukan pengujian prasyarat, yaitu uji normalitas dan uji homgenitas. 
Uji statistik yang digunakan untuk menguji normalitas yaitu dengan menggunakan metode liliefors pada taraf signifikan ( $\alpha)$ 0,05. Rangkuman hasil perhitungan uji normalitas kemampuan akhir pemahaman konsep matematis sampel dapat dilihat pada Tabel 5 dibawah ini:

Tabel 5

Rangkuman Hasil Uji Normalitas Kemampuan Akhir Pemahaman Konsep Matematis

\begin{tabular}{|c|c|c|c|c|c|c|}
\hline $\begin{array}{l}\mathbf{N} \\
\mathbf{0}\end{array}$ & Sampel & $\mathbf{N}$ & $\mathbf{L}_{\text {hitung }}$ & & Keputusan & Ket. \\
\hline 1 & $\begin{array}{l}\text { Kelas } \\
\text { Eksperimen } \\
\text { I }\end{array}$ & 37 & 0,11 & 0,15 & $\mathrm{H}_{0}$ diterima & Normal \\
\hline 2 & $\begin{array}{l}\text { Kelas } \\
\text { Eksperimen } \\
\text { II }\end{array}$ & 38 & 0,10 & 0,14 & $\mathrm{H}_{0}$ diterima & Normal \\
\hline 3 & $\begin{array}{l}\text { Kelas } \\
\text { Kontrol }\end{array}$ & 38 & 0,13 & 0,14 & $\mathrm{H}_{0}$ diterima & Normal \\
\hline
\end{tabular}

Berdasarkan Tabel 4.5 menunjukan bahwa kelas eksperimen I memperoleh $\mathrm{L}_{\text {hitung }}=0,11$ dengan $\mathrm{L}_{\text {tabel }}=$ 0,15 , kelas eksperimen II memperoleh $\mathrm{L}_{\text {hitung }}=0,10$ dengan $\mathrm{L}_{\text {tabel }}=0,14$ dan kelas kontrol memperoleh $\mathrm{L}_{\text {hitung }}$ $=0,13$ dengan $\mathrm{L}_{\text {tabel }}=0,14$. Karena $\mathrm{L}_{\text {hitung }}<\mathrm{L}_{\text {tabel }}$, maka $\mathrm{H}_{0}$ diterima. Sehingga dapat disimpulkan bahwa kelas eksperimen I, kelas eksperimen II dan kelas kontrol berasal dari populasi yang berdistribusi normal.

Pada penelitian ini, uji statistik yang digunakan untuk menguji homogenitas yaitu dengan menggunakan metode Bartlett pada taraf signifikan $(\alpha)$ 0,05. Uji homogenitas variansi digunakan untuk mengetahui apakah variansi-variansi dari sejumlah populasi sama atau tidak. Populasi yang mempunyai variansi sama disebut populasi-populasi yang homogen. Rangkuman hasil perhitungan uji homogenitas kemampuan akhir pemahaman konsep matematis sampel dapat dilihat pada Tebel 6 di bawah ini:

Tabel 6

Rangkuman Hasil Uji Homogenitas Kemampuan Akhir

\begin{tabular}{|c|c|c|c|c|}
\hline $\begin{array}{c}\text { Nama } \\
\text { Variabel }\end{array}$ & $\mathbf{X}_{\text {hitung }}$ & $\mathbf{X}_{\text {tabel }}^{2}$ & $\begin{array}{c}\text { Keputusa } \\
\mathbf{n}\end{array}$ & Ket. \\
\hline $\begin{array}{l}\text { Kelas } \\
\text { Eksperimen I, } \\
\text { Kelas } \\
\text { Eksperimen } \\
\text { II dan Kelas } \\
\text { Kontrol }\end{array}$ & 0,79 & 5,99 & $\mathrm{H}_{0}$ diterima & Homogen \\
\hline
\end{tabular}

berada diluar daerah kritis, maka $\mathrm{H}_{0}$ diterima. Sehingga dapat disimpulkan bahwa sampel berasal dari populasi bervarians homogen.

Karena uji prasyarat kemampuan akhir pemahaman konsep matematis siswa terpenuhi, dimana siswa kelas eksperimen I, kelas eksperimen II dan kelas kontrol semuanya berdistribusi normal dan homogen maka selanjutnya adalah dengan melakukan uji hipotesis. Penelitian ini menggunakan analisis variansi satu jalan dengan sel tak sama karena ketiga sampel yang akan diuji memiliki jumlah siswa yang berbeda-beda. Hasil perhitungan analisis variansi satu jalur sel tak sama dengan taraf signifikansi 0,05 disajikan pada Tabel 7 berikut:

Tabel 7

Rangkuman Analisis Variansi Satu Jalur

\begin{tabular}{cccccc}
$\begin{array}{c}\text { Sumber } \\
\text { Variansi }\end{array}$ & JK & Dk & RK & $\mathbf{F}_{\text {hitung }}$ & F $\boldsymbol{\alpha}$ \\
\hline Model & 3344,9 & 2 & 1672,47 & 5,76 & 3,08 \\
& 5 & & & & \\
Galat & 31941, & 110 & 290,38 & - & - \\
& 30 & & & - & - \\
Total & $\begin{array}{c}35286, \\
25\end{array}$ & 112 & - & - & \\
\hline
\end{tabular}

Berdasarkan Tabel 4.7 $F_{\text {hitung }}=5,76$ dan $F \alpha=3,08$, ini berarti $\mathrm{F}_{\text {hitung }}>\mathrm{F} \alpha$, maka $\mathrm{H}_{0}$ ditolak atau $\mathrm{H}_{1}$ diterima. Dengan demikian dapat disimpulkan bahwa terdapat perbedaan kemampuan pemahaman konsep matematis antara siswa yang menggunakan model pembelajran PBL dimodifikasi numbered, siswa yang menggunakan model pembelajaran PBL dan siswa yang menggunakan model pembelajaran langsung.

\section{Uji Komparasi Ganda}

Untuk menentukan model pembelajaran mana yang lebih baik terhadap kemampuan pemahaman konsep matematis, dilakukan pengujian komparasi ganda sebagai tindak lanjut setelah uji analisis variansi. Metode yang digunakan dalam uji Komparasi ganda adalah metode scheffe pada taraf signifikan 0,05. Uji komparasi hanya dapat dilakukan pada hipotesis nol yang ditolak. Rangkuman hasil perhitungan uji komparasi ganda kemampuan akhir pemahaman konsep matematis dapat dilihat pada Tabel 8 dibawah ini:

Tabel 8

Uji Schefee’ Komparasi Antar Kolom

\begin{tabular}{cc|ccc} 
Komparasi & $\mathbf{F}_{\text {hitung }}$ & $\mathbf{F} \boldsymbol{\alpha}$ & Ket. & Keputusan Uji \\
\hline $\boldsymbol{\mu}_{\mathbf{1}}$ dengan $\boldsymbol{\mu}_{2}$ & 7,49 & 6,16 & $\mathrm{~F}_{\text {hitung }}>\mathrm{F} \alpha$ & $\begin{array}{c}\mathrm{H}_{0} \text { ditolak } / \mathrm{H}_{1} \\
\text { diterima }\end{array}$ \\
$\boldsymbol{\mu}_{\mathbf{1}}$ dengan $\boldsymbol{\mu}_{3}$ & 9,72 & 6,16 & $\mathrm{~F}_{\text {hitung }}>\mathrm{F} \alpha$ & $\begin{array}{c}\mathrm{H}_{0} \text { ditolak } / \mathrm{H}_{1} \\
\text { diterima }\end{array}$ \\
$\boldsymbol{\mu}_{\mathbf{2}}$ dengan $\boldsymbol{\mu}_{3}$ & 0,15 & 6,16 & $\mathrm{~F}_{\text {hitung }}<\mathrm{F} \alpha$ & $\begin{array}{c}\mathrm{H}_{0} \text { diterima } / \mathrm{H}_{1} \\
\text { ditolak }\end{array}$ \\
\hline
\end{tabular}

Keterangan :

$\mu_{1}$ : Rata-rata kemampuan pemahaman konsep matematis siswa kelas eksperimen I yang menggunakan model pembelajaran PBL dimodifikasi numbered.

$\mu_{2:}$ Rata-rata kemampuan pemahaman konsep matenatis siswa kelas eksperimen II yang menggunakan model pembelajaran PBL. 
$\mu_{3:}$ Rata-rata kemampuan pemahaman konsep matematis siswa kelas kontrol yang menggunakan model pembelajaran langsung.

Berdasarkan Tabel 5.8 dapat disimpulkan bahwa:

a. Pada $\mu_{1}$ dengan $\mu_{2}$ diperoleh $F_{\text {hitung }}=7,49$ dan $\mathrm{F} \alpha=$ 6,16. Karena $F_{\text {hitung }}>\mathrm{F} \alpha$ maka $\mathrm{H}_{0}$ ditolak sehingga dapat disimpulkan bahwa terdapat perbedaan yang signifikan antara rata-rata kemampuan pemahaman konsep matematis siswa kelas eksperimen I yang menggunakan model pembelajaran PBL dimodifikasi numbered dengan rata-rata kemampuan pemahaman konsep matenatis siswa kelas eksperimen II yang menggunakan model pembelajaran PBL. Berdasarkan hasil penelitian diperoleh $\mu_{1}=66,24$ dan $\mu_{2}=55,47$ dimana $\mu_{1}>\mu_{2}$, artinya kemampuan pemahaman konsep matematis siswa kelas eksperimen I yang menggunakan model pembelajaran PBL dimodifikasi numbered lebih baik dari pada kemampuan pemahaman konsep matematis siswa kelas eksperimen II yang menggunakan model pembelajaran PBL

b. Pada $\mu_{1}$ dengan $\mu_{3}$ diperoleh $F_{\text {hitung }}=9,72$ dan $\mathrm{F} \alpha=$ 6,16. Karena Fhitung $>\mathrm{F} \alpha$ maka $\mathrm{H}_{0}$ ditolak sehingga dapat disimpulkan bahwa terdapat perbedaan yang signifikan antara rata-rata kemampuan pemahaman konsep matematis siswa kelas eksperimen I yang menggunakan model pembelajaran PBL dimodifikasi numbered dengan rata-rata kemampuan pemahaman konsep matenatis siswa kelas kontrol yang menggunakan model pembelajaran langsung. Berdasarkan hasil penelitian diperoleh $\mu_{1}=66,24$ dan $\mu_{3}=53,97$ dimana $\mu_{1}>\mu_{3}$, artinya kemampuan pemahaman konsep matematis siswa kelas eksperimen I yang menggunakan model pembelajaran PBL dimodifikasi numbered lebih baik dari pada kemampuan pemahaman konsep matematis siswa kelas kontrol yang menggunakan model pembelajaran langsung.

c. Pada $\mu_{2}$ dengan $\mu_{3}$ diperoleh $\mathrm{F}_{\text {hitung }}=0,15$ dan $\mathrm{F} \alpha=$ 6,16. Karena Fhitung $<\mathrm{F} \alpha$ maka $\mathrm{H}_{0}$ diterima sehingga dapat disimpulkan bahwa tidak terdapat perbedaan yang signifikan antara rata-rata kemampuan pemahaman konsep matematis siswa kelas eksperimen II yang menggunakan model pembelajaran PBL dengan rata-rata kemampuan pemahaman konsep matenatis siswa kelas kontrol yang menggunakan model pembelajaran langsung.

Berdasarkan hasil posttest dapat disimpulkan bahwa: (1) Terdapat perbedaan kemampuan pemahaman konsep matematis antara siswa yang menggunakan model pembelajran PBL dimodifikasi numbered, siswa yang menggunakan model pembelajaran PBL dan siswa yang menggunakan model pembelajaran langsung; (2)
Kemampuan pemahaman konsep matematis siswa yang menggunakan model pembelajaran PBL dimodifikasi numbered lebih baik daripada siswa yang menggunakan model pembelajaran PBL; (3) Kemampuan pemahaman konsep matematis siswa yang menggunakan model pembelajaran PBL dimodifikasi numbered lebih baik daripada siswa yang menggunakan model pembelajaran langsung. (4) Tidak terdapat perbedaan kemampuan pemahaman konsep matematis antara siswa yang menggunakan model pembelajaran PBL dengan siswa yang menggunakan model pembelajaran langsung.

Berdasarkan analisis data, untuk hipotesis kedua yang menuturkan bahwa kemampuan pemahaman konsep matematis siswa yang menggunakan model pembelajaran PBL dimodifikasi numbered lebih baik daripada siswa yang menggunakan model pembelajaran PBL. Baik dalam proses pembelajaran PBL dimodifikasi numbered maupun dalam proses pembelajran PBL, siswa dibagi kedalam beberapa kelompok yang beranggotakan 4-5 orang kemudian setiap masing-masing kelompok berdiskusi untuk menyelesaikan/menemukan solusi dari permasalahan yang diberikan. Berbeda dengan model pembelajran PBL, pada model pembelajran PBL dimodifikasi numbered setiap anggota kelompok siswa diberi number yang mana number tersebut bermanfaat untuk menentukan perwakilan kelompok yang akan mempresentasikan hasil diskusi kelompoknya. Dengan begitu siswa lebih termotivasi dan bertanggungjawab untuk memahami materi ajar yang dipelajari sehingga mendorong penguasaaan konsep matematis siswa. Siswa yang lemah pemahamannya akan terpacu untuk belajar pada teman kelompok yang memiliki tingkat pemahaman tinggi agar bisa paham terhadap konsep yang dipelajari, sehingga dapat melatih siswa dalam bekerjasama secara kelompok.

Untuk hipotesis ketiga yang menuturkan bahwa kemampuan pemahaman konsep matematis siswa yang menggunakan model pembelajaran PBL dimodifikasi numbered lebih baik daripada siswa yang menggunakan model pembelajaran langsung. Hal ini disebabkan karena dalam proses pembelajaran langsung masih berkonsep ceramah sehingga menimbulkan kurangnya partisipasi siswa dalam proses pembelajaran. Hal tersebut sejalan dengan pendapat Rosdiani (2013: 155) yang mengemukan bahwa jika terlalu sering menggunakan model pembelajaran langsung akan membuat siswa percaya bahwa guru akan memberitahu siswa semua yang perlu diketahui. Hal ini akan menghilangkan rasa tanggung jawab mengenai pembelajaran siswa itu sendiri.

Sedangkan hipotesis keempat yang menuturkan bahwa kemampuan pemahaman konsep matematis siswa yang menggunakan model pembelajaran PBL tidak lebih baik dari siswa yang menggunakan model pembelajaran 
langsung. Dilihat dari data posttest menunjukkan bahwa antara rerata kemampuan pemahaman konsep matematis yang menggunakan model pembelajaran PBL dengan model pembelajaran langsung hasilnya sama atau tidak terdapat perbedaan. Tetapi pada proses pembelajaran dilapangan kedua model tersebut sangat berbeda jauh. Model pembelajaran langsung yang pelaksanaannya satu arah (teacher center) tanpa ada feedback dari siswa. Sehingga menimbulkan kurangnya motivasi dan tanggungjawab siswa dalam memahami isi materi yang disampaikan. Hal tersebut sejalan dengan pendapat Rosdiani (2013: 155) yang menyatakan bahwa model pembelajaran langsung akan membuat siswa percaya bahwa guru akan memberikan siswa semua yang perlu diketahui. Berbeda halnya dengan model pembelajaran PBL, dalam proses pembelajaran PBL siswa diberi suatu permasalahan yang kemudian diarahkan untuk berdiskusi dan bekerjasama secara berkelompok untuk mencari solusi permasalahan yang diberikan sehingga siswa pun ikut berperan aktif dalam proses pembelajaran. Sanjaya (dalam Wulandari dkk. 2012: 2) mengemukakan bahwa melalui PBL bisa memperlihatkan kepada siswa setiap mata pelajaran (matematika, IPA, dan lain sebagainya), pada dasarnya merupakan cara berpikir, dan sesuatu yang harus dimengerti oleh siswa, bukan hanya sekadar belajar dari guru atau buku-buku saja.

\section{PENUTUP}

\section{Simpulan}

Berdasarkan hasil analisis data dan pembahasan dapat ditarik kesimpulan sebagai berikut:

1. Terdapat perbedaan kemampuan pemahaman konsep matematis antara siswa yang menggunakan model pembelajran PBL dimodifikasi numbered dengan siswa yang menggunakan model pembelajaran PBL dan siswa yang menggunakan model pembelajaran langsung.

2. Kemampuan pemahaman konsep matematis siswa yang menggunakan model pembelajaran PBL dimodifikasi numbered lebih baik daripada siswa yang menggunakan model pembelajaran PBL.

3. Kemampuan pemahaman konsep matematis siswa yang menggunakan model pembelajaran PBL dimodifikasi numbered lebih baik daripada siswa yang menggunakan model pembelajaran langsung.

4. Kemampuan pemahaman konsep matematis siswa yang menggunakan model pembelajaran PBL tidak lebih baik daripada siswa yang menggunakan model pembelajaran langsung.

\section{Saran}

Dalam pelaksanaan model pembelajaran Problem Based learning (PBL) Dimodifikasi Numbered, terlebih dahulu guru harus menyampaikan rencana kegiatan proses pembelajaran yang akan dilakukan secara rinci dan jelas kepada siswa, sehingga siswa dapat menyesuaikan diri dengan proses rencana pembelajaran yang akan dilaksanakan. Kemudian, hendaknya lebih memperhatikan alokasi waktu, aktivitas siswa dan tahapan-tahapan dalam pembelajaran, sehingga tujuan pembelajaran dapat tercapai secara maksimal. Selain itu juga, guru harus memberikan arahan dan motivasi kepada seluruh siswa, sehingga siswa bisa lebih aktif dalam mengemukakan gagasannya dan bisa bertanggagung jawab terhadap kelompoknya.

\section{DAFTAR PUSTAKA}

Al Tabany, T. I. B. (2014). Mendesain Model Pembelajaran Inovatif, Progresif, dan Kontekstual: Konsep, Landasan, dan Imlementasinya pada Kurikulum 2013 (Kurikulum Tematik Integratif/TKI). Pertama. Jakarta: Prenada Media Group.

Amir, M. Taufik. (2015). Inovasi Pendidikan Melalui Problem Based Learning: Bagaimana Pendidik Memperdayakan Pemelajar di Era Pengetahuan. Pertama. Jakarta: Prenada Media Group.

Anggoro, R.P. (2015). "Pengaruh Pembelajaran Kooperatif Tipe NHT dan TAI dengan Pendekatan Kontekstual Terhadap Partisipasi dan prestasi Belajar Matematika ". Jurnal Pendidikan Matematika. 10 (1): 71-79

Arifin, Z. (2012). Evaluasi Pembelajaran. Jakarta Pusat: Direktorat Jendral Pendidikan Islam Kementrian Agama.

Budiyono. (2009). Statistika untuk Penelitian. Kedua. Surakarta: UPT Penerbitan.

Darmawan, D. (2013). Metode Penelitian Kuantitatif. Bandung: PT Remaja Rosdakarya.

Hasratudin. (2014). "Pembelajarn Matematika Sekarang dan yang akan Datang Berbasis Karakter". Jurnal Didaktik Matematika. 1 (2): 30-42.

Hidayat, U. S. (2011). Model-Model Pembelajaran Berbasis PAIKEM. Bandung: CV. Siliwangi \& Co

Kartini, D. V. (2014). "Peningkatan Kemampuan Pemahaman Matematis dan Sikap Positif Terhadap Matematika Siswa SMP Nasrani 2 Medan Melalui Pendekatan Problem Posing". Jurnal Saintech. 4 (4): 93-105. 
Kesumawati. (2008). "Pemahaman konsep matematik dalam Pembelajaran Matematika". Seminar Matematika dan Pendidikan Matematika. halaman 2-229

Lestari, K.E. dan Yudhanegara, M.R. (2015). Penelitian Pendidikan Matematika: Panduan Praktis Menyusun Skripsi, Tesis, dan Laporan Penelitian dengan Pendekatan Kuantitatif, Kualitatif, dan Kombinasi Disertai dengan Model Pembelajaran dan Kemampuan Matematis. Pertama. Bandung: PT Refika Aditama.

Maryati., Asnawati, R. dan Nurhanurawati. (2013). "Upaya Meningkatkan Akitivitas dan Pemahamn Konsep Matematis Siswa Melalui Model Pembelajaran Kooperatif Tipe STAD”. Jurnal Pendidikan Matematika. 2, (2): 81-87.

Murizal, A. Yarman. Yerizon. (2012). "Pemahaman Konsep Matematika dan Model Pembelajaran Quantum Teaching". Jurnal Pendidikan Matematika. 1 (1): 19-23.

Musfiqon, H. M. (2012). Metodologi Penelitian Pendidikan. Jakarta: PT. Prestasi Pustakarya.

Ramlan, M. (2013). "Meningkatkan Self-Efficacy Pada Pembelajaran Matematika Melalui Model kooperatif Tipe Team Assisted Individualization (TAI) Pada Siswa VIIA SMP Negeri 27 Makasar". Jurnal Matematika dan Pembelajaran (MAPAN). 1 (1): 110-121

Retnowati, D. dan Murtiyasa, B. (2013). "Upaya Meningkatkan Pemahaman Konsep dan Disposisi Matematis Menggunakan Model Pembelajaran Treffinger". Seminar Nasional Pendidikan Matematika. halaman 14-23

Rosniani, D. (2013). Model Pembelajaran Langsung dalam Pendidikan Jasmani dan Kesehatan. Pertama. Bandung: Alfabeta.

Sani, R. A. (2014). Inovasi Pembelajaran. Pertama. Jakarta: Bumi Aksara

Sugiyono. (2015). Metode Penelitian Pendidikan: Pendekatan Kuantitatif, kualitatif, dan $R \& D$. Pertama. Bandung: Alfabeta.

Suleman, A. R. (2013). Upaya Meningkatkan Pemahaman Konsep Penjumlahan di SDN 3 Tapa kabupaten Bone Bolango.

Sumartini, T. S. (2015). "Peningkatan Kemampuan Penalaran Matematis Siswa Melalui Pembelajaran Berbasis Masalah". Mosharafa Jurnal Pendidikan Matematika .5 (1), 10 halaman.
Sundayana, R. (2010). Statistika Penelitian Pendidikan. Garut: STKIP Garut Press.

Susanto, A. (2014). Teori Belajar dan Pembelajaran di Sekolah Dasar. Pertama. Jakarta: Kencana, Prenada Media Group

Utomo, T., wahyuni, D. dan Hariyadi, S. (2014). "Pengaruh Model Pembelajaran Berbasis Masalah (Problem Based Learning) Terhadap Pemahaman Konsep dan Kemampuan Berfikir Kreatif Siswa”. Jurnal Edukasi UNEJ. 1 (1): 5-9.

Ulia, N. (2014). "Peningkatan Pemahaman Konsep Matematika Materi Bangun Datar dengan Model Pembelajaran Kooperatif Tipe Group Investigation dengan Pendekatan Saintifik di SD”. Jurnal Tunas Bangsa. 55-68.

Pratama, A. S. (2016). “Penerapan Model Problem Based Learning untuk Meningkatkan Hasil Belajar pada Mata Pelajaran Sosiologi Kelas X-3 SMA Negeri 1 Mojolaban”. Jurnal Skripsi.

Wulandari, E., Budi, H. S. dan Suryandari, K. C. (2012). Penerapan Model PBL (Problrm Based Learning) pada Pembelajaran IPA Siswa Kelas V SD.

Yamin, M. (2013). Strategi \& Metode dalam Model Pembelajaran. Pertama. Jakarta: Referensi (GP Press Group). 